\title{
Modeling of Asphalt Pavement Considering the Application of Empirical and Mechanistic Design Methodologies
}

\author{
Fernando Jove Wilches*1, Álvaro Rafael Caballero Guerrero² and Giancarlo Patrón Lambraño ${ }^{3}$ \\ ${ }^{1}$ Department of Civil Engineering, Universidad de Sucre, Sincelejo, Sucre, Colombia. \\ ${ }^{2}$ Department of Civil and Environmental Engineering, Universidad del Norte, Barranquilla, Colombia. \\ ${ }^{3}$ Faculty of Engineering, Universidad Tecnológica de Bolivar, Turbaco, Colombia.
}

ORCIDs: 0000-0002-2080-4036 (Fernando), 0000-0002-3567-9135 (Álvaro), 0000-0002-1044-8648 (Giancarlo)

\begin{abstract}
Road infrastructure projects are essential for the economic growth and development of a country, because they provide great advantages in the mobility of people, as well as goods or consumer products, thus making it possible for transport costs to be cheaper and thus also improving the safety and comfort of road users. In Colombia, the main transportation system is made up of highways, most of which are projected on asphalt structures. For Colombia, as for many Latin American countries, the most commonly used method for the design of asphalt pavements is the AASHTO 1993, on which some design manuals implemented by the Instituto Nacional de Vias (INVIAS) of Colombia are based, as is the case of the Manual de Diseño de Pavimentos Asfálticos en Vías con Medios y Altos Volúmenes de Tránsito. The AASHTO method allows to determine from proposed pavement structures, the number of admissible repetitions that it can withstand in terms of equivalent standard axles of 8.2 tons. This is an empirical method based on trials, field tests and experience, which has been used for a long time. However, at present the use of design methods that are based more on the properties and mechanical behavior of materials is gaining popularity, which are called mechanistic methods. The purpose of this work is to compare the results obtained in the design of asphalt pavement structures by the methods of the AASHTO 1993, the INA, the SHELL and the Transport and Road Research Laboratory (TRRL), from 7 traffic steps $(\mathrm{Wt}=10,000,50,000,100,000,500,000$, $1,000,000,5,000,000$ and 10,000,000 of standard $80 \mathrm{kN})$ and for three subgrade conditions of the foundation soils $(\mathrm{CBR}=$ 3.0, 5.0 and 10.0\%). The pavement structure selected for this study consisted of an asphalt layer supported on a granular base that in turn rested on the subgrade. For the calculation of the deformations generated in the proposed models and used to apply the mechanistic methods, the PITRA PAVE and EVERSTRESS FE software were used, which are based on elastic theory and finite element theory, respectively.
\end{abstract}

Keywords: Asphalt pavements, fatigue laws, AASHTO-93 method, Mechanistic methods, Pavement design

\section{INTRODUCTION}

Transport systems are made up of infrastructure, vehicles and their operating characteristics [1] and make it possible to move or move people or goods from one place to another, using some type of vehicle. This characteristic gives it great importance in today's society. Hence, having an adequate road infrastructure for land transport is important for the functioning of the modern economies of the countries [2].

The economic and social development of the communities is directly linked to the state of the transportation systems. Thus, the development and growth of a region or an entire country may be diminished by the insufficiency of transportation systems, which can have negative effects on the entire population of the region or country where this occurs.

In this work, emphasis will be placed on road infrastructure, which is made up of the physical elements that make it possible to move vehicles comfortably and safely from one place to another, such as pavements, tunnels, bridges, systems signage, drainage systems and landscaping elements. Pavements are considered the basic elements in road infrastructure systems, because they provide the rolling surfaces in accordance with the geometric design and category of the roads, and the needs of the means of transport, being one of the elements that requires the greatest amount of economic resources for its construction, maintenance and rehabilitation [1].

The importance of pavements within the elements that make up the road infrastructure, make it almost mandatory to carry out studies aimed at carrying out optimized designs, in order to find solutions according to the conditions of each project, with the intention of providing the conditions of safety and comfort at the lowest possible cost. Preserving the road infrastructure in good condition is important to avoid operating cost overruns in the transport of people and goods, taking into account that the countries that allow the deterioration of their road infrastructure will have considerable cost overruns in their economy [3], causing very large investments must be made in the conservation of its road network.

Based on the aforementioned, the optimization of the designs of road pavements is an essential task so that they achieve adequate behavior during the entire service life of the structures. 
Current technology in the area of pavements allows the design of various alternatives that guarantee the stability and rehabilitation of the works over time [4], leading to the design and construction of pavement structures more in line with the requirements to which they are going to be submitted.

Pavement design methodologies, according to the Federal Highway Administration, can be classified into three broad categories: empirical design, mechanistic design, and mechanistic-empirical design. The empirical design approach is one that is based solely on the results of experiments or experiences, making use of trials and field tests. The mechanistic design approach is based on the theories of mechanics and material properties and relates the behavior and structural performance of the pavement with traffic loading and environmental influences. The mechanical-empirical pavement design approach combines characteristics of both the mechanistic and empirical approaches, according to the characteristics of the project [5].

The current methodologies for the design of pavements in most of the Latin American countries are empirical [6], where the design is protected in the knowledge of the physical properties of the materials and some bearing resistance index, such as the case of CBR [7], without taking into consideration many times the mechanics of the materials that make up the pavement structure. On the other hand, there is an increase in the application of mechanistic methodologies for the design of pavement structures, which tend to have a more scientific rigor before the actions of vehicular traffic and the climate of the project area.

In many South American countries, such as Colombia, the flexible pavement design method of AASHTO 93 [8] is still used, which can be considered as an empirical or semiempirical method [7], but which is far from the purely mechanistic methods, in which fatigue models are used to estimate the stresses and strains admissible, to later be compared with the calculated acting actions [9]. In the case of Colombia, there are no calibrations for local conditions, which is why pavement designers are forced to resort to fatigue laws developed in foreign countries with material and environmental conditions different from those of the country, which can cause high uncertainty in pavement sizing and long-term performance.

The present work aims to make a comparison between different design methodologies, and at the same time, to compare different fatigue laws to observe the behavior and sensitivity of typical designs of pavement structures in Colombia. Different flexible pavement structures were designed through the AASHTO 1993 methodology, and then the design was made through mechanistic mechanisms making use of the PITRA PAVE and EVERSTRESS FE software, which use conventional and finite element theory, respectively, to through which the stresses, tensile and tensile forces were obtained, which were compared using three different fatigue models: the SHELL, the INA and the TRRL.

\section{MATERIALS AND METHODS}

The methodology used to prepare this study is summarized in four stages, which will be described in this section.
The first stage consisted of determining the characteristics and conditions of the pavement structures to be designed. For this purpose, it was decided to select a typical asphalt pavement structure representative of Colombia's highways, which consisted of an asphalt layer supported on a granular base, materials that must meet the specifications of the Instituto Nacional de Vias (INVIAS). The proposed structure is supported by various foundation soils, which simulate different typical soil conditions found in the country. The typical pavement structure selected can be seen in Fig. 1, and the information regarding the properties and characteristics of the materials that make up said structure can be consulted in Table 1 .

The traffic was characterized using the recommendation established in the AASHTO 1993 methodology, in which a single axle with double wheel with a total weight of $80 \mathrm{kN}$ is taken as a reference, which is called the equivalent single axle load (ESAL) [10]. Characteristic transits were taken for low, medium and high vehicle volumes, according to the INVIAS asphalt pavement design standards. The design transits analyzed were: 10,000, 50,000, 100,000, 500,000, 1,000,000, 5,000,000 and 10,000,000 ESALs.

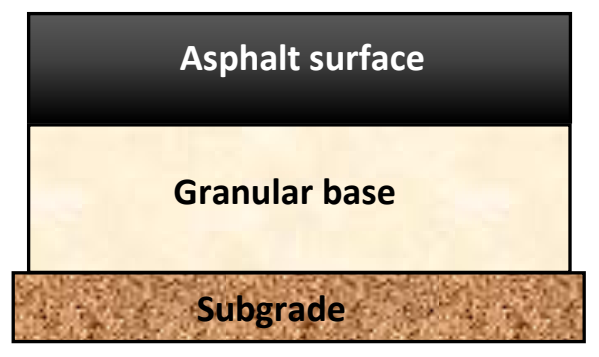

Fig. 1. Structural model for design

Table 1. Properties of the materials used in the designs

\begin{tabular}{ccc}
\hline Material & Variable & Values \\
\hline \multirow{3}{*}{$\begin{array}{c}\text { Subgrade } \\
\text { soils }\end{array}$} & California Bearing Ratio (CBR, \%) & $3,5,10$ \\
& Poisson's Ratio & 0.50 \\
& Young's Modulus (Mpa) & $30,50,100$ \\
Granular & Density $\left(\mathrm{kg} / \mathrm{m}^{3}\right)$ & 1900 \\
Base & Poisson's Ratio & 0.40 \\
& Young's Modulus $(\mathrm{Mpa})$ & 200 \\
\hline \multirow{2}{*}{ Asphalt } & Density $\left(\mathrm{kg} / \mathrm{m}^{3}\right)$ & 2150 \\
Concrete & Poisson's Ratio & 0.35 \\
& Young's Modulus $(\mathrm{Mpa})$ & 2500 \\
\hline
\end{tabular}

The second stage was carried out once the structure to be designed and its characteristics had been established, and consisted in determining the thicknesses of the asphalt layer and the granular layer for the different traffics considered. The method of the AASHTO version 1993 was used, one of the most common empirical methods in the design of asphalt 
pavements in the country [10], [11]. Through this methodology, the so-called structural number $(\mathrm{SN})$ required to protect each of the support layers of the structural package is determined, to later determine the combination of thicknesses of the different layers of the pavement, which satisfy the design conditions. To obtain the required structural number, Equation 1 is applied. Then, from the required structural numbers, the thicknesses of the different layers that make up the pavement structure are determined, using Equation 2.

$$
\begin{aligned}
\log _{10} W 18=Z_{R} \cdot S_{0} & +9.36 \cdot \log _{10}(S N+1)-0.20+\frac{\log _{10}\left[\frac{\Delta P S I}{4.2-1.5}\right]}{0.40+\frac{1094}{(S N+1)^{5.19}}} \\
& +2.32 \cdot \log _{10} M_{R}-8.07
\end{aligned}
$$

Where:

W18: Predicted number of $80 \mathrm{kN}$ equivalent single axle loads. ZR: Normal standard deviation associated with the design reliability $\mathrm{R}$.

So: Combined standard error.

Pi: Initial serviceability index.

Pf: Final serviceability index.

$\mathrm{SN}$ : Structural number (inches).

MR: Effective resilient modulus of the subgrade soil (psi).
$S N=\left(a_{1}\right)\left(D_{1}\right)+\left(a_{2}\right)\left(m_{2}\right)\left(D_{2}\right)+\left(a_{3}\right)\left(m_{3}\right)\left(D_{3}\right)$

Where:

SN: Structural number (in)

ai: Structural coefficient for the asphalt layer i

Di: Thickness of the asphalt layer i (in)

mi: Drainage coefficient of the granular layer $i$

The third stage consisted of modeling the pavement structures obtained in the previous step, in order to determine the stresses and deformations that are generated in the pavement structure, this in order to apply mechanistic methods and verify the behavior of the designed structures.

For this work, free software was used, which were Pitra Pave v1.0, which is a tool for the mechanical analysis of flexible pavements based on the classic multilayer theory developed by the National Laboratory of Structural Materials and Models (LanammenURC) of the University of Costa Rica, and the EverStressFE v1.0 software, which is a tool for 3D finite element analysis, to simulate the response of flexible asphalt pavement systems subjected to vehicular loads, developed by the professor Bill Davids of the University of Maine.

\begin{tabular}{|c|c|c|}
\hline Material & Variable & Value \\
\hline $\begin{array}{l}\text { North American } \\
\text { Asphalt Institute (IA } \\
\text { 1991) }\end{array}$ & $N_{f}=0.1595 \times \varepsilon_{t}^{-3.291} \times E c a^{-0.854}$ & $\begin{array}{l}N f: \text { Number of repetitions to cause fatigue cracking } \\
E c a \text { : Dynamic modulus of the asphalt mix, in psi } \\
\varepsilon \text { t: Tensile strain in the lower fiber of the asphalt layer of } \\
\text { the model under analysis. }\end{array}$ \\
\hline $\begin{array}{l}\text { SHELL Modified } \\
\text { Method }\end{array}$ & $N_{f}=\left(\frac{0.856 V b+1.08}{E c a^{0.36} * \varepsilon_{t}}\right)^{5}$ & $\begin{array}{l}N f: \text { Number of repetitions to cause fatigue cracking } \\
E c a \text { : Dynamic modulus of the asphalt mix, in Pascals } \\
V b: \text { Effective asphalt volume of the asphalt mix, in } \% \text {. } \\
\varepsilon \mathrm{t} \text { : Tensile strain in the lower fiber of the asphalt layer of } \\
\text { the model under analysis. } \\
\text { Expression for } 95 \% \text { reliability. }\end{array}$ \\
\hline TRRL Method & $N_{f}=1.66 \times 10^{-10} \times \varepsilon_{t}^{-4.32}$ & $\begin{array}{l}N f: \text { Number of repetitions to cause fatigue cracking } \\
\mathcal{E} \mathrm{t}: \text { Tensile strain in the lower fiber of the asphalt layer of } \\
\text { the model under analysis }\end{array}$ \\
\hline
\end{tabular}

Table 2. Fatigue laws for the acceptable radial deformation at the base of the asphalt layers

After running the asphalt pavement models in both softwares, the deformations at the points of interest were obtained, for the application of the fatigue cracking models and the permanent deformation models, as expressed in equations 3 and 4 [6].

In the case of fatigue cracking, this is associated with the accumulated damage that occurs in the lower fiber of the asphalt layers and can be expressed as:

$$
N_{f}=f_{1} \varepsilon_{t}^{-f 2} \times E_{1}^{-f 3}
$$

Where Nf, is the number of admissible repetitions; et, the stress deformations in the lower fiber of the asphalt layer; E1 is the modulus of elasticity of the asphalt layer, and f1, $\mathrm{f} 2$ and $\mathrm{f} 3$, are constant to calibrate the model with laboratory tests and observation of the behavior of scale models in the field.

In the case of permanent deformation, this is associated with the vertical compression deformation in the upper fiber of the subgrade layer and can be expressed as:

$$
N_{z}=f_{4} \varepsilon_{c}^{-f 5}
$$

Where Nz, is the number of admissible repetitions; ec, is the vertical compression deformation in the upper fiber of the subgrade, and $\mathrm{f} 4$ and $\mathrm{f} 5$ are also constant to calibrate the model with laboratory tests and observation of the behavior of scale models in the field. 
The last stage of the research consisted in determining the admissible transits that the designed pavement structures can support, for which different Fatigue laws were used. The first two Fatigue models used were those of Shell and INA [12], which are recommended in the Manual de Diseño de Pavimentos Asfálticos en Vías con Medios y Altos Volúmenes de Tránsito. Subsequently, the fatigue model proposed by TRRL [13] was used. In Table 2 and Table 3, the formulations for each of these laws of fatigue can be observed. Based on the aforementioned fatigue laws, the admissible transits that the structures can withstand were determined by mechanistic methods.

Tabla 3. Fatigue laws for the calculation of the admissible vertical deformation in the subgrade

\begin{tabular}{|c|c|c|}
\hline Material & Variable & Value \\
\hline $\begin{array}{l}\text { North American } \\
\text { Asphalt Institute } \\
\text { (IA 1991) }\end{array}$ & $N_{z}=1.365 \times 10^{-9} \times \varepsilon_{z}^{-4.477}$ & $\begin{array}{l}\mathrm{N} \text { : Number of repetitions of load per axle allowed } \\
\text { for rut control. } \\
\varepsilon \text { z: Vertical compression deformation of the } \\
\text { subgrade of the model under analysis. }\end{array}$ \\
\hline $\begin{array}{l}\text { SHELL Modified } \\
\text { Method }\end{array}$ & $N_{z}=1.05 \times 10^{-7} \times \varepsilon_{z}^{-4}$ & $\begin{array}{l}\text { N: Number of repetitions of load per axle allowed } \\
\text { for rut control. } \\
\varepsilon \text { z: Vertical compression deformation of the } \\
\text { subgrade of the model under analysis. } \\
\text { Expression for } 95 \% \text { reliability. }\end{array}$ \\
\hline TRRL Method & $N_{z}=6.18 \times 10^{-8} \times \varepsilon_{z}^{-3.95}$ & $\begin{array}{l}\mathrm{N} \text { : Number of repetitions of load per axle allowed } \\
\text { for rut control. } \\
\varepsilon \text { z: Vertical compression deformation of the } \\
\text { subgrade of the model under analysis. }\end{array}$ \\
\hline
\end{tabular}

\section{RESULTS}

The results of this work refer to the design of a flexible pavement structure for different load levels, expressed in terms of Equivalent Single Axle Load (ESAL); as well as different levels of bearing capacity of the subgrade.

Fig. 2 and Fig. 3 show the effect generated by the difference in the bearing capacity of the subgrade soils, in the results obtained for the unit deformations through the Pitra Pave and EverStress FE programs. According to Fig. 2, it can be noted that for the same level of traffic, the EverStress FE program shows a deformation $\varepsilon$ f greater than that obtained through the Pitra Pave software. On the other hand, as the bearing capacity of the subgrade increases, for a given deformation, it is observed that the level of admissible traffic is higher.

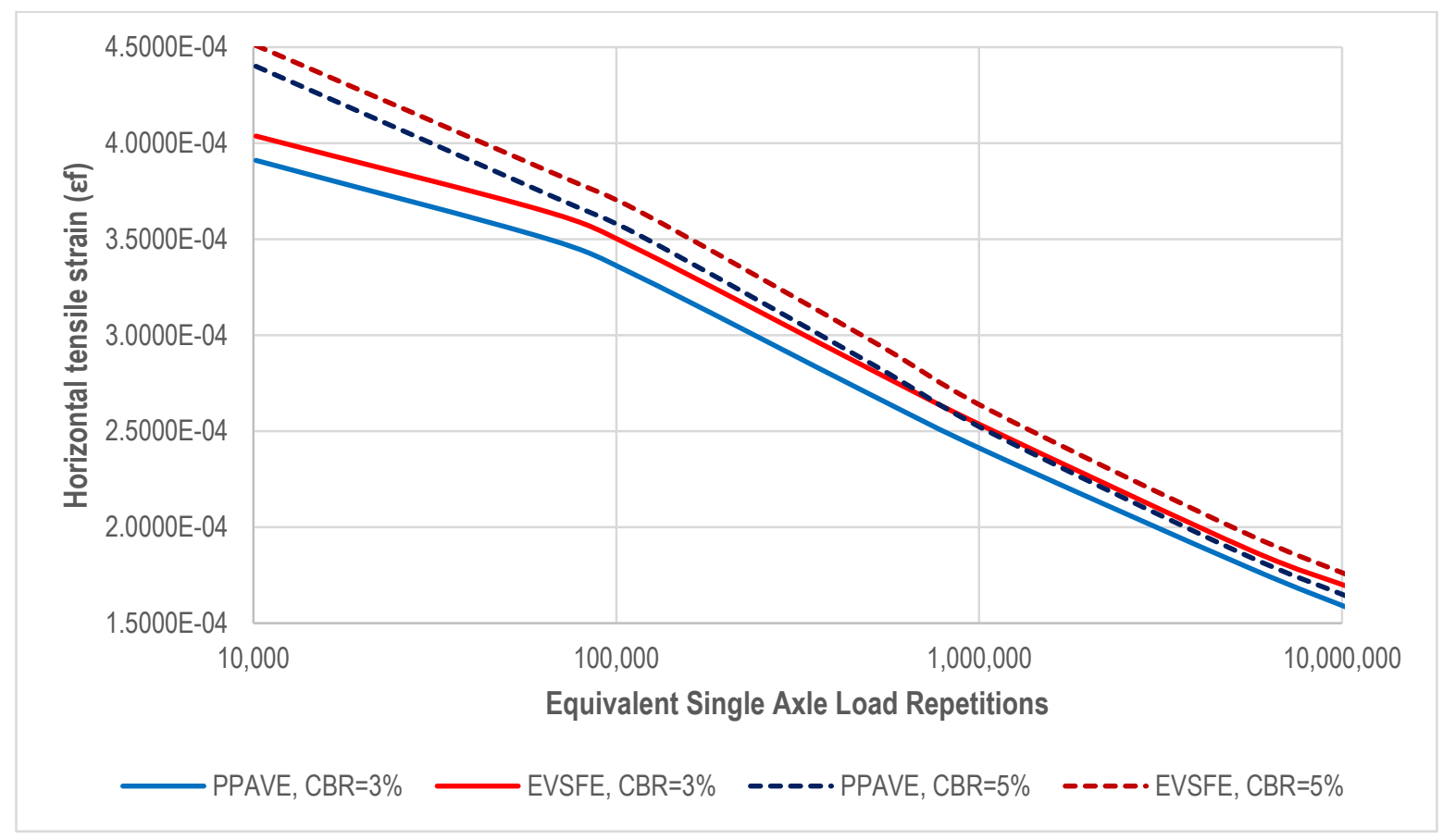

Fig. 2. Comparison of horizontal tensile strain at the bottom of the asphalt layer 
International Journal of Engineering Research and Technology. ISSN 0974-3154, Volume 13, Number 11 (2020), pp. $3919-3926$

(C) International Research Publication House. https://dx.doi.org/10.37624/IJERT/13.11.2020.3919-3926

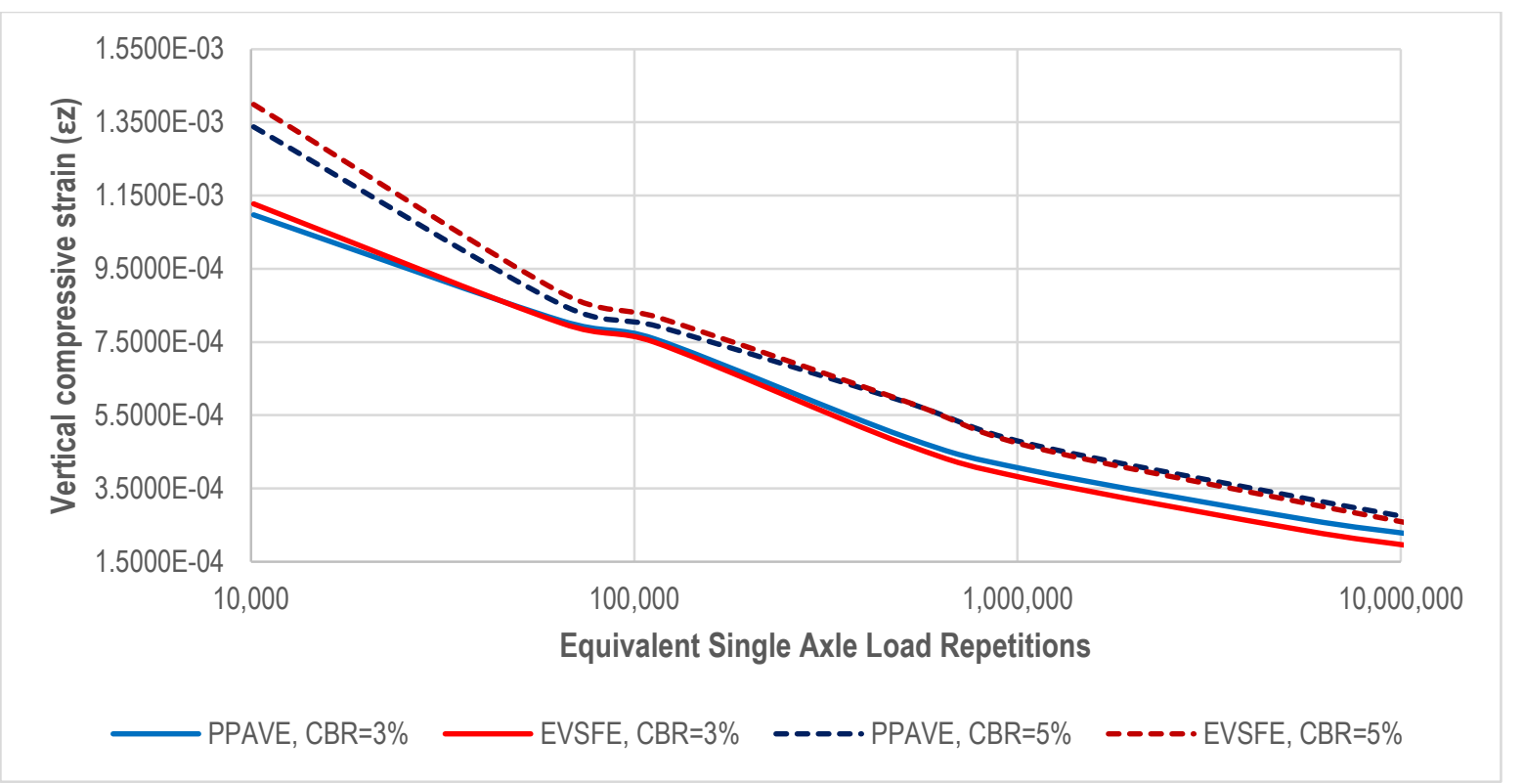

Fig. 3. Comparison of vertical compressive strain at the top of the subgrade

In Table 4, the results of the modeling of the pavement structures by the AASHTO-93 method are presented, as well as the results of the horizontal tensile deformations in the lower part of the asphalt layer and the vertical compression deformation in the upper part of the subgrade, obtained from the PITRA PAVE (PPAVE) and EVERSTRESS FE (EVSFE) software, for different traffic categories: 10,000, 50,000,
$100,000,500,000, \quad 1,000,000,5,000,000$ and $10,000,000$ ESALs, and different values of the resilient modulus of the subgrade, with which the foundation soil conditions of the structures were simulated with $\mathrm{CBR}=3, \mathrm{CBR}=5$ and $\mathrm{CBR}=$ $10 \%$. The thicknesses were rounded by excess, to 5 millimeters, in the case of asphalt concrete and to 5 centimeters, in the case of the Granular Base.

Table 4. Results of the modeling of pavement structures using the AASHTO-93 method and stress and compression strains obtained through rational methodology

\begin{tabular}{|c|c|c|c|c|c|c|c|c|}
\hline \multirow{2}{*}{$\begin{array}{l}\text { Design } \\
\text { Traffic }\end{array}$} & \multirow{2}{*}{$\begin{array}{c}\text { Subgrade, } \\
\text { E (MPa) }\end{array}$} & \multicolumn{2}{|c|}{ Design Results } & \multirow{2}{*}{$\begin{array}{c}\text { ESALs } \\
\text { AASHTO }\end{array}$} & \multicolumn{2}{|c|}{$\begin{array}{c}\text { Strains } \\
\text { (PITRA PAVE v1.0) } \\
\end{array}$} & \multicolumn{2}{|c|}{$\begin{array}{c}\text { Strains } \\
\text { (EVERSTRESS FE v1.0) }\end{array}$} \\
\hline & & $\begin{array}{l}\text { Asphalt } \\
\text { Concrete }\end{array}$ & $\begin{array}{l}\text { Granular } \\
\text { Base }\end{array}$ & & $\varepsilon f$ & $\varepsilon \mathbf{z}$ & $\varepsilon \mathbf{f}$ & $\varepsilon \mathbf{z}$ \\
\hline 10,000 & 30 & 5.0 & 25 & 10,171 & $3.9092 \mathrm{E}-04$ & $1.0969 \mathrm{E}-03$ & $4.0357 \mathrm{E}-04$ & $1.1272 \mathrm{E}-03$ \\
\hline 10,000 & 50 & 5.0 & 15 & 10,171 & 4.4007E-04 & $1.3381 \mathrm{E}-03$ & 4.5089E-04 & $1.3989 \mathrm{E}-03$ \\
\hline 10,000 & 100 & 5.0 & 12 & 10,171 & 4.2343E-04 & $1.0441 \mathrm{E}-03$ & 4.3847E-04 & $1.0856 \mathrm{E}-03$ \\
\hline 50,000 & 30 & 7.5 & 30 & 64,534 & $3.5008 \mathrm{E}-04$ & 8.0774E-04 & $3.6416 \mathrm{E}-04$ & $8.0146 \mathrm{E}-04$ \\
\hline 50,000 & 50 & 7.5 & 20 & 64,534 & $3.7351 \mathrm{E}-04$ & 8.5246E-04 & $3.8576 \mathrm{E}-04$ & $8.8456 \mathrm{E}-04$ \\
\hline 50,000 & 100 & 7.5 & 12 & 64,534 & $3.7853 \mathrm{E}-04$ & 7.5298E-04 & $3.8831 \mathrm{E}-04$ & 7.8739E-04 \\
\hline 100,000 & 30 & 8.5 & 30 & 113,193 & $3.3119 \mathrm{E}-04$ & $7.5797 \mathrm{E}-04$ & $3.4524 \mathrm{E}-04$ & 7.4911E-04 \\
\hline 100,000 & 50 & 8.5 & 20 & 116,093 & $3.5198 \mathrm{E}-04$ & $7.9206 \mathrm{E}-04$ & $3.6438 \mathrm{E}-04$ & $8.1624 \mathrm{E}-04$ \\
\hline 100,000 & 100 & 8.5 & 12 & 122,756 & 3.5301E-04 & $6.7305 \mathrm{E}-04$ & $3.6271 \mathrm{E}-04$ & 7.0479E-04 \\
\hline 500,000 & 30 & 11.0 & 40 & 505,864 & $2.6868 \mathrm{E}-04$ & $4.9162 \mathrm{E}-04$ & $2.8181 \mathrm{E}-04$ & 4.7172E-04 \\
\hline 500,000 & 50 & 11.0 & 25 & 500,809 & $2.8556 \mathrm{E}-04$ & 5.8901E-04 & $2.9754 \mathrm{E}-04$ & $5.9084 \mathrm{E}-04$ \\
\hline 500,000 & 100 & 11.0 & 12 & 505,864 & $2.9351 \mathrm{E}-04$ & $5.2553 \mathrm{E}-04$ & $3.0265 \mathrm{E}-04$ & $5.5721 \mathrm{E}-04$ \\
\hline $1,000,000$ & 30 & 12.5 & 45 & $1,061,823$ & $2.3892 \mathrm{E}-04$ & $4.0075 \mathrm{E}-04$ & $2.5128 \mathrm{E}-04$ & $3.7624 \mathrm{E}-04$ \\
\hline $1,000,000$ & 50 & 12.5 & 30 & $1,061,823$ & 2.4989E-04 & 4.7314E-04 & $2.6133 \mathrm{E}-04$ & 4.6636E-04 \\
\hline $1,000,000$ & 100 & 12.5 & 12 & $1,027,389$ & $2.6251 \mathrm{E}-04$ & $4.6096 \mathrm{E}-04$ & $2.7134 \mathrm{E}-04$ & 4.9207E-04 \\
\hline $5,000,000$ & 30 & 16.5 & 55 & $5,561,172$ & $1.7867 \mathrm{E}-04$ & $2.6599 \mathrm{E}-04$ & $1.8824 \mathrm{E}-04$ & $2.3551 \mathrm{E}-04$ \\
\hline $5,000,000$ & 50 & 16.5 & 35 & $5,191,205$ & $1.8716 \mathrm{E}-04$ & 3.2991E-04 & $1.9852 \mathrm{E}-04$ & $3.1739 \mathrm{E}-04$ \\
\hline $5,000,000$ & 100 & 16.5 & 15 & $5,087,265$ & $1.9319 \mathrm{E}-04$ & $3.3727 \mathrm{E}-04$ & $2.0294 \mathrm{E}-04$ & $3.4756 \mathrm{E}-04$ \\
\hline $10,000,000$ & 30 & 18.5 & 60 & $11,074,590$ & $1.5586 \mathrm{E}-04$ & $2.2232 \mathrm{E}-04$ & $1.6719 \mathrm{E}-04$ & $1.9011 \mathrm{E}-04$ \\
\hline $10,000,000$ & 50 & 18.5 & 40 & $11,074,590$ & $1.6182 \mathrm{E}-04$ & $2.6603 \mathrm{E}-04$ & $1.7301 \mathrm{E}-04$ & $2.5032 \mathrm{E}-04$ \\
\hline $10,000,000$ & 100 & 18.5 & 20 & $11,074,590$ & 1.6493E-04 & $2.7791 \mathrm{E}-04$ & $1.7465 \mathrm{E}-04$ & $2.7996 \mathrm{E}-04$ \\
\hline
\end{tabular}


International Journal of Engineering Research and Technology. ISSN 0974-3154, Volume 13, Number 11 (2020), pp. $3919-3926$

(C) International Research Publication House. https://dx.doi.org/10.37624/IJERT/13.11.2020.3919-3926

Table 5 shows the admissible transits obtained, in accordance with the INA, SHELL and TRRL fatigue laws, using the
PitraPave and Everstress FE software, considering different thicknesses of asphalt layer and granular base.

Table 5. Design transits estimated by the INA, SHELL and TRRL Fatigue laws

\begin{tabular}{|c|c|c|c|c|c|c|c|c|c|c|}
\hline \multirow{2}{*}{$\begin{array}{l}\text { Design } \\
\text { Traffic }\end{array}$} & \multirow{2}{*}{$\begin{array}{l}\text { Subgrade, } \\
\text { E (Mpa) }\end{array}$} & \multicolumn{2}{|c|}{ Design Results } & \multirow{2}{*}{$\begin{array}{c}\text { ESALs } \\
\text { AASHTO }\end{array}$} & \multicolumn{3}{|c|}{ ESALs (PITRA PAVE v1.0) } & \multicolumn{3}{|c|}{ ESALs (EVERSTRESS FE v1.0) } \\
\hline & & $\begin{array}{c}\text { Asphalt } \\
\text { Concrete }\end{array}$ & $\begin{array}{c}\text { Granular } \\
\text { Base } \\
\end{array}$ & & INA & SHELL & TRRL & INA & SHELL & TRRL \\
\hline 10,000 & 30 & 5.0 & 25 & 10,171 & 24,339 & 72,531 & 30,362 & 21,544 & 65,041 & 27,264 \\
\hline 10,000 & 50 & 5.0 & 15 & 10,170 & 9,996 & 32,752 & 13,847 & 8,193 & 27,418 & 11,618 \\
\hline 10,000 & 100 & 5.0 & 12 & 10,171 & 30,355 & 88,353 & 36,894 & 25,494 & 75,598 & 31,630 \\
\hline 50,000 & 30 & 7.5 & 30 & 64,534 & 95,781 & 246,662 & 101,687 & 99,187 & 254,485 & 104,871 \\
\hline 50,000 & 50 & 7.5 & 20 & 64,534 & 75,250 & 198,835 & 82,191 & 63,773 & 171,506 & 71,026 \\
\hline 50,000 & 100 & 7.5 & 12 & 64,534 & 131,151 & 294,150 & 100,627 & 107,372 & 258,927 & 90,127 \\
\hline 100,000 & 30 & 8.5 & 30 & 113,193 & 127,330 & 318,113 & 130,726 & 134,212 & 333,432 & 136,941 \\
\hline 100,000 & 50 & 8.5 & 20 & 116,093 & 104,567 & 266,782 & 109,874 & 91,395 & 236,547 & 97,568 \\
\hline 100,000 & 100 & 8.5 & 12 & 122,756 & 216,753 & 416,999 & 136,040 & 176,347 & 364,143 & 121,007 \\
\hline 500,000 & 30 & 11.0 & 40 & 505,864 & 884,519 & $1,632,650$ & 442,396 & $1,064,261$ & $1,286,139$ & 359,995 \\
\hline 500,000 & 50 & 11.0 & 25 & 500,809 & 393,816 & 872,366 & 340,013 & 388,385 & 861,608 & 284,703 \\
\hline 500,000 & 100 & 11.0 & 12 & 505,864 & 656,172 & $1,049,435$ & 301,979 & 504,901 & 900,257 & 264,511 \\
\hline $1,000,000$ & 30 & 12.5 & 45 & $1,061,823$ & $2,208,350$ & $2,936,347$ & 734,611 & $2,005,093$ & $2,281,814$ & 590,780 \\
\hline $1,000,000$ & 50 & 12.5 & 30 & $1,061,823$ & $1,050,035$ & $2,095,225$ & 605,108 & $1,120,127$ & $1,875,528$ & 498,713 \\
\hline $1,000,000$ & 100 & 12.5 & 12 & $1,027,389$ & $1,180,082$ & $1,833,752$ & 489,100 & 880,903 & $1,554,178$ & 423,963 \\
\hline $5,000,000$ & 30 & 16.5 & 55 & $5,561,172$ & $6,159,598$ & $12,554,855$ & $2,577,775$ & $5,187,731$ & $9,671,867$ & $2,057,561$ \\
\hline $5,000,000$ & 50 & 16.5 & 35 & $5,191,205$ & $5,275,651$ & $8,863,543$ & $2,109,346$ & $4,354,923$ & $7,413,931$ & $1,635,286$ \\
\hline $5,000,000$ & 100 & 16.5 & 15 & $5,087,265$ & $4,762,981$ & $8,114,812$ & $1,839,308$ & $4,050,488$ & $6,640,971$ & $1,486,893$ \\
\hline $10,000,000$ & 30 & 18.5 & 60 & $11,074,590$ & $9,655,272$ & $24,854,014$ & $4,650,443$ & $7,664,242$ & $17,499,209$ & $3,434,311$ \\
\hline $10,000,000$ & 50 & 18.5 & 40 & $11,074,590$ & $8,533,543$ & $20,601,978$ & $3,954,476$ & $6,847,972$ & $14,747,346$ & $2,962,378$ \\
\hline $10,000,000$ & 100 & 18.5 & 20 & $11,074,590$ & $8,015,325$ & $17,602,429$ & $3,642,282$ & $6,638,615$ & $14,067,825$ & $2,844,067$ \\
\hline
\end{tabular}

In Figures 4, 5 and 6, the representative curves of the design transits obtained by the INA, SHELL and TRRL methods are compared with the design curve of the AASHTO-93 method; using Pitra Pave and EverStress FE software. Figures 4, 5 and 6 were constructed for three levels of subgrade bearing capacity: $\mathrm{CBR}=3,4$ and $5 \%$, respectively.
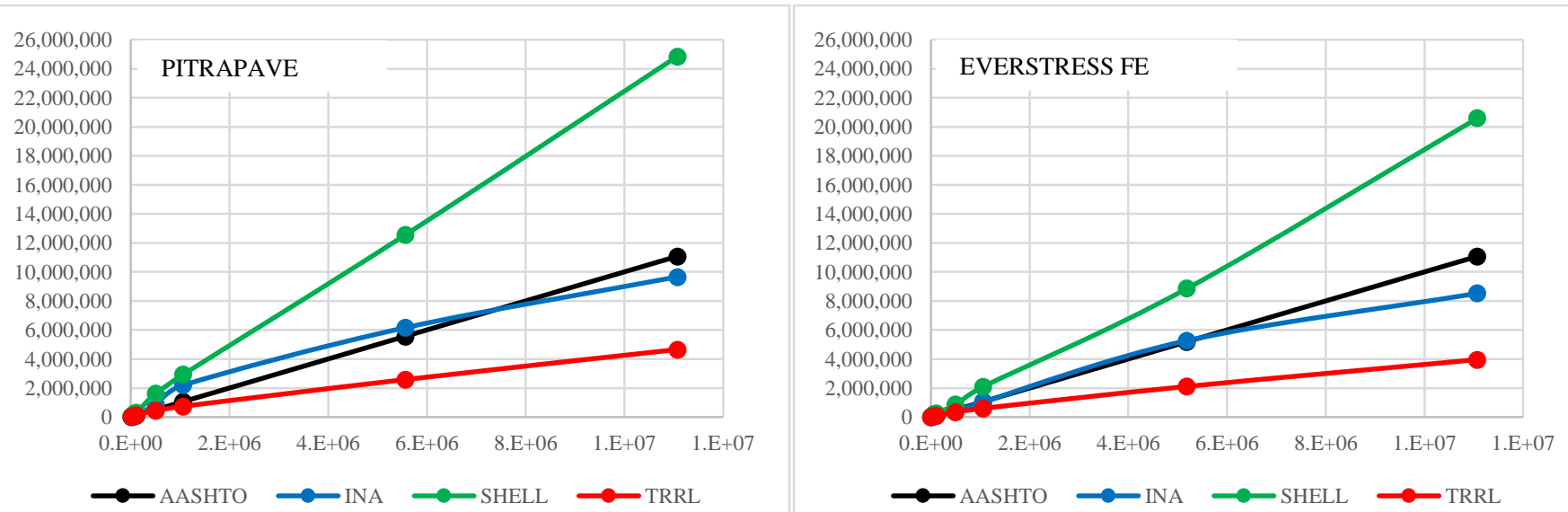

Fig. 4. Comparison of Traffic by the AASHTO, INA, SHELL and TRRL methods, by Pitra and EverStress FE for CBR = 3.0\% 

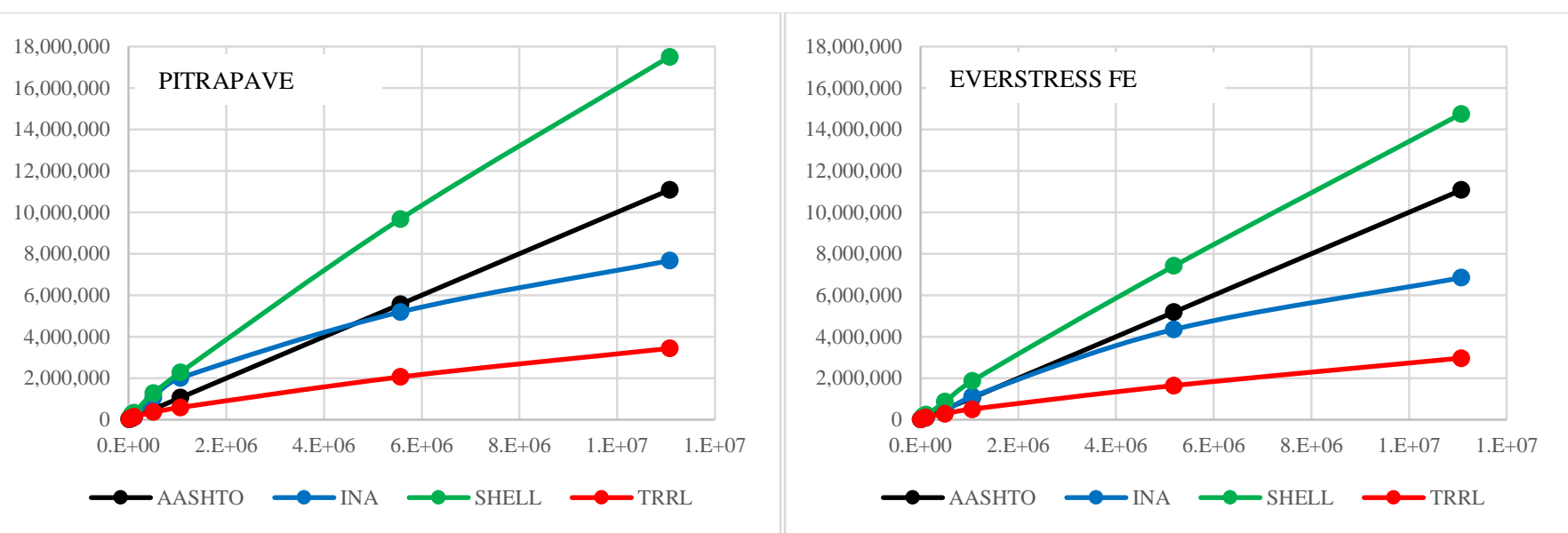

Fig. 5. Comparison of Traffic by the AASHTO, INA, SHELL and TRRL methods, by Pitra and EverStress FE for CBR = 5.0\%
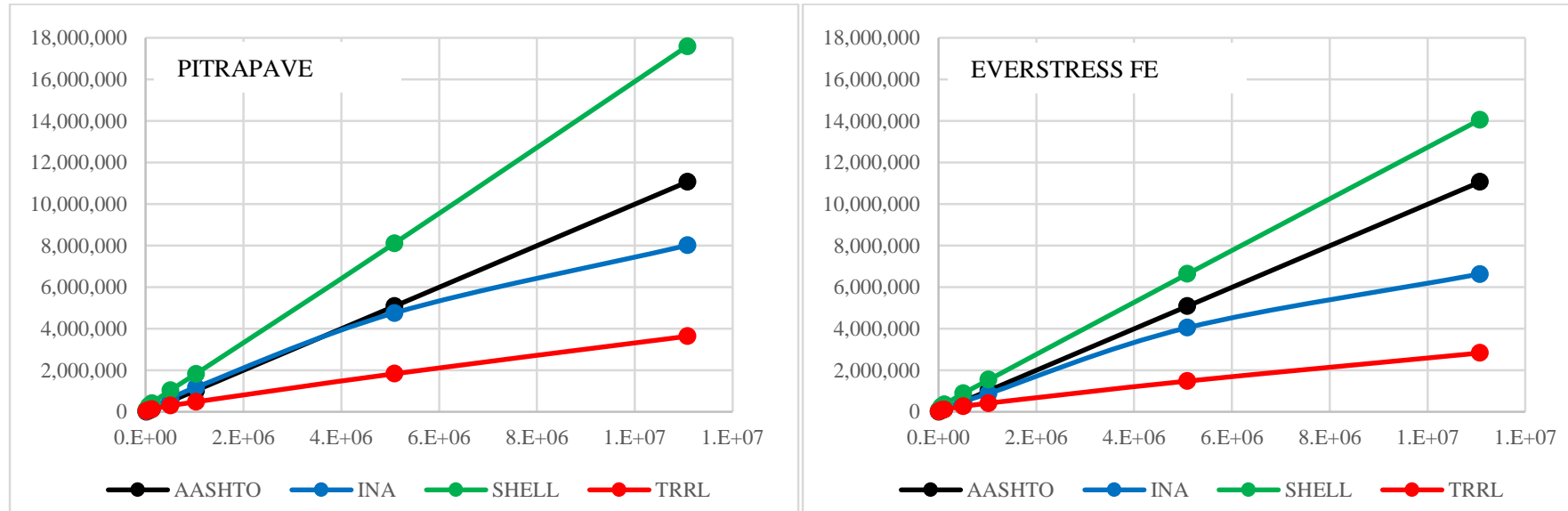

Fig. 6. Comparison of Traffic by the AASHTO, INA, SHELL and TRRL methods, by Pitra and EverStress FE for CBR = 10.0\%

\section{CONCLUSIONS}

According to the results obtained in the modeling, it can be concluded:

The PitraPave and EverStress FE softwares are two software that can be used to determine the deformations generated by a load in flexible pavement structures. When modeling the structures with the Finite Element program, tensile and compressive unit deformations were obtained a little higher than those calculated with the Pitra Pave program. This difference may be due to the nature and difference of both analysis methodologies, thus, for example, the Finite Elements program needs a mesh, which can vary the results for the same model with the same properties. Additionally, the software based on finite elements is designed to yield the maximum values of deformation, while with the other software, arbitrary points must be taken to obtain the parameters sought, which can generate greater uncertainty in obtaining of the maximum values.

In the case of subgrade soils, it is observed that as the quality of support increases, for the same level of traffic, the deformations decrease. This is particularly evident when the results obtained for $\mathrm{E}=30 \mathrm{MPa}$ and $\mathrm{E}=50 \mathrm{MPa}$ are compared.
Regarding the fatigue laws used, it is observed that in most cases, the laws provided by the TRRL are quite conservative, yielding lower admissible transits than those obtained by the AASHTO 1993 method. Only in the cases where since traffic is low (less than 200,000 ESALs), the TRRL laws give less conservative results. In the case of the SHELL fatigue laws, it is observed that these yield admissible transits well above the other methods used, which means that the structures obtained by this methodology could be undersized. In the case of the INA fatigue laws, the behavior of the design curve depends on the traffic level considered and the bearing capacity of the subgrade, and it can be observed that for high transits and high bearing capacity, the responses obtained allow obtaining more conservative structures than those obtained through the AASHTO-93 and SHELL methods.

\section{ACKNOWLEDGMENTS}

The authors thank the engineer Edilberto Elias Contreras Sierra for the contributions made in the development of the manuscript. 


\section{REFERENCES}

[1] Solminihac H, Echeveguren T, Chamorro A, Gestión de Infraestructura Vial: Tercera edición, Ediciones UC, Santiago de Chile, 2018.

[2] Ruiz J, El transporte por carretera, 2da Edición, Marge Books, Barcelona, 2011.

[3] Macea-Mercado L, Morales L, Márquez-Díaz L, Un sistema de gestión de pavimentos basado en nuevas tecnologías para países en vía de desarrollo, Ingeniería, Investigación y Tecnología, Volume 17, Issue 2, 2016, pp. 223-236. Doi: https://doi.org/10.1016/j.riit.2016.06.007

[4] Rico A, Téllez R, Garnica P, Pavimentos Flexibles: Problemática, Metodologías de Diseño y Tendencias, Instituto Mexicano del Transporte, Sanfandila, Qro, 1998. https://www.imt.mx/archivos/Publicaciones/PublicacionT ecnica/pt104.pdf

[5] Federal Highway Administration FHWA, Geotechnical Aspects of Pavements. Publication No. FHWA NHI-05037. Washington: Federal Highway Administration. U.S. Department of Transportación. Chapter 3. 2006. Recuperado de: https://www.fhwa.dot.gov/engineering/geotech/pubs/050 37/03b.cfm\#s05a

[6] Garnica P, Gómez J, Sesma J, Mecánica de materiales para pavimentos, Sanfandila, Instituto Mexicano del Transporte, Qro, 2002. Recuperado de: https://www.imt.mx/archivos/Publicaciones/PublicacionT ecnica/pt197.pdf

[7] Garnica P, Correa A, Conceptos mecanicistas en pavimentos, Instituto Mexicano del Transporte, Sanfandila, Qro, 2004. Recuperado de: https://www.imt.mx/archivos/Publicaciones/PublicacionT ecnica/pt258.pdf

[8] Rodríguez M, Thenoux G, González A, Probabilistic assessment of asphalt pavement design, Revista Ingeniería de Construcción, Vol 31 No2, 2016.Recuperado de: https://scielo.conicyt.cl/scielo.php?script=sci_arttext\&pid $=$ S0718-50732016000200002\&lng=en\&tlng=en

[9] Orobio A, Gil J, Construction cost analysis related to the mechanistic design of pavements with different fatigue models. Revista Ingeniería de Construcción. Vol 30 Nº3, 2015. Recuperado de: https://scielo.conicyt.cl/scielo.php? script=sci_arttext\&pid=S0718-

$50732015000300003 \& \operatorname{lng}=$ en $\& n r m=i s o \& t \operatorname{lng}=e n$

[10] American Association of State Highway and Transportation Officials, AASHTO Guide for Design of Pavement Structures, Washington, D.C., 1993.

[11] Montejo A, Ingeniería de pavimentos, 3th edition, Universidad Católica de Colombia, Bogotá, 2016.

[12] Ministerio de Transporte, Manual de Diseño de Pavimentos Asfalticos en Vías con Medios y altos Volúmenes de Transito, Instituto Nacional de Vías, Bogotá, D.C., 2015.

[13] Sandoval H, Hernando C, Leyes de comportamiento de la deformación radial admisible de tracción en pavimentos flexibles. Facultad de Ingeniería, vol. 16, núm. 23, 2007, pp. 47-58. Disponible en: http://www.redalyc.org/ articulo.oa?id=413940756005 